\title{
Analysis of Factors That Affecting Farmers Membership Participation on Agricultural Cooperative: - In Case of Ana Lemo District, Hadiya Zone, SNNPR, Ethiopia
}

\author{
Abel Wudenah Abamaga* \\ Department of Economics, Woliata Sodo University, P.O. Box 138, Woliata Sodo, Ethiopia
}

\begin{abstract}
Cooperative early play and currently as well playing important role on socio-economic status of community for long time even if, they face different challenges and weakness. The study was conducted at agricultural cooperative in Ana Lemo district at Hadiya Zone, SNNPR. It intended in identifying factors that affects households membership participation in agricultural cooperatives. Multi-stage sampling method is conducted to define sample size from the target population on Ana Lemo district. Primary data in this study was collected through structured questionnaire based on 110 agricultural cooperative members' respondents and 110 from non-members respondents from purposively selected five kebeles in Ana Lemo district. Total 220 household were selected by using two stage sampling method. Secondary data were gathered from agricultural cooperative and marketing office of district and Hadiya zone cooperative and marketing sectors. Both are quantitative and qualitative in nature. Data analysis is carried out with the help of various descriptive like chi $^{2}$ and t-test also econometric techniques were employed i.e logit model. The final results of study indicate that rural household participation on agricultural cooperative determined by being household head male, high education level, fertilizer amount that household used via yearly, access for agricultural extension, using yearly improved agricultural seed, appearance of household in wheat production and awareness about agricultural cooperative service affect household participation and associated positively and high market distance, having other opportunity for credit from financial institution also affect rural household participation and negatively correlated. So government and other concerned stockholders should support household in order to increase their usage of those agriculture input to increase membership and governments should include on its policy and give more reflexion on awareness creation on practise of agricultural improved seed and fertilizer on cooperatives.
\end{abstract}

Keywords: Agriculture cooperative, participation, Logit model, membership.

DOI: $10.7176 / \mathrm{DCS} / 9-10-01$

Publication date:October $31^{\text {st }} 2019$

\section{CHAPTER ONE}

\section{INTRODUCTION}

Using collective action to deal with social and economic challenges has a long tradition in Ethiopia. The concept of cooperative is not new idea, even before formation of modern cooperative. In Ethiopia cooperative state by cooperation among society /community to solve socio-economic problem which found in most are mutual aid institution like Equb, Eddir, Gejja, Senbete and others. This traditional cooperation among rural and urban community was alerted to modern cooperation in Ethiopia starting during Emperor Haileselase regime in 1961 (Zerihun, 1998).

Early in Ethiopia, cooperative challenged by government policy and being participation on cooperative membership were by force and also it is use as source for government revenue through time this still cause negative perception on rural farmers to participate agricultural cooperative and on its objective activities. However, after the downfall of the Derg regime in 1991, agricultural cooperatives in Ethiopia have become an integral part of the country wide strategy for agricultural transformation (MoFED, 2006).

Those modern cooperative have its own principle and business practices which especially made cooperative successful (Kimberly and Robert, 2004). Modern cooperative is autonomous association of person united voluntarily to meet their common economic, social and cultural needs (ICA, 1995). In other way ICA explained cooperative as it is autonomous association of persons united to meet their common economic, social and cultural need voluntarily and aspiration through owned and democratically controlled enterprise, through this principle share out of the profit that make accrue from business (ILO, 2002).

In most countries modern cooperative established aim on different objectives specifically for government intervention in community. According to Clegg (2006) in developing countries like Ethiopia cooperative formation is for strategic intervention by government in order to promote farmers participation in supply chain, to reduce barriers to assets, information, services, input and output market. Cooperative support member farmers in different ways like in improving agricultural productivity, income and expenditure since it create competitive market for farmers produce and supplying agricultural input. 
According to Abel (2006) agricultural cooperative build individual capacities by improving participant income, asset and food status of households and participation in cooperative has been recognized as a gifted strategy for smallholders to overcome market imperfection by access to market distance and new agricultural technologies, which in turn rise their productivity and income (Birchall, 2003). Many actors suggest that agricultural cooperatives have providing infinite service for rural households explicitly more in agricultural production activities, marketing and provide opportunity for poor people to rise their income (ILO, 2007) and members are employed direct and indirect to meet several MDGs such as education and reduce children mortality (Birchal, 2004).

Correspondingly other scholars indicate cooperatives improve saving habit and provide way out of poverty for rural household (Smith and Ross, 2006) and agricultural cooperative in other side link smallholder farmers with international and domestic market and pool them to produce more (Shiferaw et al, 2012). Furthermore most actor believe on potential role of cooperative on employment, market facility, negotiating better price, providing agricultural input, accessing credit and the way for small farmers to exit from poverty (Burgess et al,2003; Birchall, 2003; ILO, and ICA, 2012 and IFAD,2013). Henceforth, cooperative considered as appropriate tool to support agricultural activities even though they are facing critical problem which may reduce their positive role. Problem like lack of coordination, inefficient distribution of resource, low education attainment and other invisible reason government intervention negatively the rate of participation to agricultural cooperative (Hernanz and Espandrdo, 2002; Cheochan et al, 2000; Hansen et al, 2002; Handson and Hernododo, 2003).

Even if, cooperative have those vast multi-dimensional service for their members, however participation of rural household were minimal in Ana Lemo district. Moreover, knowledge about determinates of household participation in agricultural cooperative is limited in study area. Therefore this study intended in identifying factors that affects rural household participation on membership in agricultural cooperatives.

\section{RESEARCH DESIGN AND METHOD}

\subsection{Description of the study area}

The study was conducted in Ana Lemo district in Hadiya zone at south nation nationality people region. Administrative center town of Ana Lemo district is Fonko town, which located at about $218 \mathrm{~km}$ from capital city Addis Ababa to the south and $192 \mathrm{~km}$ from regional administrative centre Hawasa through Hosanna. The total population of Ana Lemo district is 105,514 out of this 50,143 were male and 55,371 were female and $96 \%$ of which live in rural area were mostly subsistence farmers depending on rain fed agricultural production the remained $4 \%$ were urban dwellers. The weather condition of the district is more suitable for wheat, teff and maize production. In addition to those cereal various types of crop such as barely, sorghum, bean and field pea are cultivated in area. Location is 51" north latitude and 37.0.51"-38.0.06 East longitude. The area experience type of rainfall classified as small from March to April and main rain seasons are from July to September (ALWFEDO, 2018) Ana Lemo Woreda Finance and Economic Development office yearly report.

\subsection{Sampling Method and Sample Size}

The study was conducted on agricultural cooperative at Hadiya zone, in case of Ana lemo district. Multi-stage sampling method is conducted to define sample size from the target population on Ana Lemo district. At the first stage, five kebeles were purposively selected from each cluster in district namely; Debub Fonko, Meserk Daresha, Wogela, Hachamo and Chingo kebeles.

This is based on their cooperative potential activities performance, agro-ecological difference since district has difference ecology and to reduce probability of tumbling all five kebeles in one cluster. Hence, investigator selects purposively total five kebeles that means from each cluster one in study area.

In second stage stratify total population of sample kebeles' household in to two stratums those members and non-members. The first stratum is from agricultural cooperative participants who are already member of agricultural cooperative and second stratum is from non-members. At kebele level representative respondents from both was selected by using simple random sampling method from each members and non-members. According the data obtained that found on Ana-Lemo woreda agricultural and cooperative office the total target population of purposively selected five kebeles were 2200 households. Investigator takes ideal $10 \%$ of from this total sample kebeles to determine sample size. Therefore, 220 sample sizes were taken for this study because this fulfill minimum ideal sample size household for reliable results. Representative sample size from each selected kebeles and from participants and non-participants an agricultural cooperative that was assigned depend on their proportion.

\subsection{Method of Data Collection and Source of Data}

The primary data for this study were collected from selected kebeles both agricultural cooperative participants and non-participants respondents on district. Secondary data were gathered from agricultural cooperative and marketing office of Ana Lemo district and Hadiya zone cooperative and marketing sectors. 
The Primary data was collected from the sampled respondents of both cooperative members and nonmembers on different characteristic such as demographic and socio-economic characteristics of households by means of structured questionnaire which pre-tested prior to its use in the field. That questionnaire was first prepared in English language, then it translated in to Hadiyisa and Amharic language to facilitate the interview process. Also secondary data was used for this study from internet, reports, books, journals, articles, and working papers.

\subsection{Methods of Data Analysis}

\subsubsection{Model specification}

In investigation both descriptive statistics and econometric model were employed. Specifically, descriptive statistics such as percentage, mean, standard deviation, and t-test for continues variables and chi $^{2}$ for dummy variables was employed to identify main variables those influence rural house hold participation and also logit model from econometric model were employed. Logit model was used as well to identify determining factors of rural household participation on multipurpose primary cooperative.

$\mathrm{P}=\mathrm{E}(\mathrm{Y}=1 / \mathrm{Xi})=\frac{1}{1+e^{\beta 0+\beta i X i}}$

Then $\mathrm{p}_{\mathrm{i}}=\frac{1}{1+e^{-z i}}$ for household participate in cooperative.

$1-\mathrm{Pi}=\frac{1}{1+e^{z i}}$ for household not participate in cooperative.

$\frac{P_{i}}{1-P_{i}}=\frac{1+e^{Z} i}{1+e^{-Z}}$

$\frac{P_{i}}{1-P_{i}}$, The odds ratio in the favor of participating in the cooperative to the probability of household not participate.

To normalize take natural $\log$

$\mathrm{Li}=\ln \left(\frac{P_{i}}{1-P_{i}}\right)=\mathrm{Zi}=\beta_{0}+\beta_{1} \mathrm{X}_{1}+\beta_{2} \mathrm{X}_{2}+\beta_{3} \mathrm{X}_{3}+\beta_{4} \mathrm{X}_{4}+-----+\beta_{\mathrm{n}} \mathrm{X}_{\mathrm{n}}$

Where; $\mathrm{P}_{\mathrm{i}}=$ is a probability of being participated in the program

$\mathrm{Z}_{i}=$ is a function of explanatory variables $\left(X_{\mathrm{i}}\right)$ which is also expressed as:

$\beta_{0}=$ is an intercept

$\beta_{1}, \beta_{2}, \cdots \beta_{n}=$ are slopes of the equation in the model,

$L_{i}=$ is $\log$ of odds ratio which is not only linear in $X_{i}$ but also linear in the parameters,

$\left(X_{i}\right)=$ observable characteristics if the disturbance term $\left(u_{i}\right)$ is introduced to the logit model

$Z_{i}=\beta_{0}+\beta_{1} X_{1}+\beta_{2} X_{2}+\beta_{3} X_{3}+\cdots+\beta_{n} X_{n}+u_{i}$

\subsubsection{Variable specification}

Dependent variable: - The dependent variable for this study was the probability of rural house head that participate on membership on multipurpose primary agricultural cooperatives. The variable indicate dichotomous /binary/ variable which takes the value 1 if household head participate in cooperative and it takes the value 0 if a household did not participate in cooperative (not member of cooperative).

\section{Explanatory variables}

The explanatory variables in the logit analysis include the demographic and socio-economic characteristics of rural households that hypothesized to influence participation of households' in agricultural cooperative positively or negatively. Those listed below in table:- 
Table 1. Description, types and expected value of variables

\begin{tabular}{|c|c|c|c|}
\hline Variables & Variable name & Variable description & $\begin{array}{l}\text { Expected } \\
\text { sign }\end{array}$ \\
\hline $\mathbf{Y}$ & $\begin{array}{l}\text { Whether households head } \\
\text { participate in cooperatives }\end{array}$ & Dummy variables $($ Yes $=1$, No $=0)$ & \\
\hline Hhsex & Sex of household head & Dummy variable $($ Male $=1 ;$ Female $=0)$ & + \\
\hline Hhmartial & Household head martial & Dummy variable (Married=1; Unmarried $=0$ ) & +1 \\
\hline Fmsize & Number of family members & Continuous variable ; expected in people & \\
\hline Hhage & Household head age & Continuous variable; expected in year & ? \\
\hline Hhedu & Household head education status & $\begin{array}{l}\text { Continuous variable; expected by level of } \\
\text { education }\end{array}$ & + \\
\hline Mktdist & Market distance from their home & Continuous variable; expected in $\mathrm{km}$ & + \\
\hline Offfarm & Household head off-farm income & Continuous variable; $(\mathrm{Yes}=1 ; \mathrm{No}=0)$ & \\
\hline Totafert & $\begin{array}{l}\text { Total amount of fertilizer that } \\
\text { household used }\end{array}$ & Continuous variable ; expected by kilogram & + \\
\hline Landha & $\begin{array}{l}\text { Household cultivated land holding } \\
\text { in hector }\end{array}$ & Continuous variable; expected by hector & + \\
\hline Othcredacc & Other credit access for Household & Dummy variable; $($ Yes $=1$, No $=0)$ & \\
\hline Impseedus & Using improved agricultural seed & Dummy; $($ Yes $=1$, No $=0$ & + \\
\hline Khh & $\begin{array}{l}\text { Knowledge of household head } \\
\text { about agricultural cooperative }\end{array}$ & Dummy variable $($ Yes $=1$, No $=0)$ & + \\
\hline WheatP & $\begin{array}{l}\text { Household head wheat production } \\
\text { level per year }\end{array}$ & Continuous variable; expected by kilogram & + \\
\hline Agrexte & $\begin{array}{l}\text { Household access for agricultural } \\
\text { extension in kebele }\end{array}$ & Dummy $($ Yes $=1$, No $=0)$ & + \\
\hline
\end{tabular}

\section{RESULTS AND DISCUSSION}

\subsection{Descriptive Analysis}

\subsubsection{Household characteristic for discrete variables}

Under this part main focus was in analysis of demographic and socio economic characteristic of respondent household heads. At this juncture on discrete demographic and socio-economic variables six of them are strongly significantly different between cooperative members and non-members rural household in study area. As revealed in table 2 below from respondents household head that (92\%) are male and remained (8\%) female head from those agricultural cooperative participants besides non-participants on membership $78.72 \%$ were male and $21.28 \%$ female headed households, the result revealed that household head sex significantly affect participation in agricultural cooperative membership with significance level $5 \%\left(X^{2}=5.51 * *\right)$.

With respect to by using improved seed on respondents there is significant difference among participants and non-participants at agricultural cooperative, from participants that use improved seed was $77.6 \%$ and remaining $22.4 \%$ are non-user and from non-participants $51 \%$ use improved seed, left over part $49 \%$ were non-user. Those result entails that there is significant variance between cooperative participant and non-participant at $1 \%\left(X^{2}=\right.$ $\left.12.71^{* * *}\right)$ significance level. Which implies house hold demand for improve seed significantly determine arrival decision of households membership on agricultural cooperative. In case of other credit access from total cooperative member respondents $84.21 \%$ house hold inform that have no any credit access and for non-members were $67 \%$, but only $15.79 \%$ from member and $32 \%$ are have other credit access in area. This show significance difference between members and non-members on other credit access at significance level $1 \%\left(X^{2}=6.57^{* * *}\right)$ which reveal that having other credit access affect households participation on agricultural cooperatives in study area. Off-farm income between participants and non-participants group that enormous percent of member respondents $93.4 \%$ have no off-farm income and $68.1 \%$ from non-members this show high difference between both group and it was statistically significant at significance level $1 \%\left(X^{2}=6.49^{* * *}\right)$ which infers households have off-farm activities significantly determine decision of entrance on agricultural cooperative and in case of households awareness about cooperatives and its service there is significant different among members and nonmembers that $84.2 \%$ and $45.7 \%$ of respondents were aware about service of primary cooperatives respectively this show that household awareness about agricultural cooperatives statistically affect membership participation of rural households at $1 \%$ significance level with $\mathrm{X}^{2}$ - value $\left(26.65^{* * *}\right)$. Lastly, based on extension service most of cooperative members had get extension service that $64.5 \%$ and from those non-members $61.7 \%$ and remand $35.5 \%$ from participants and in aggregate result show that there is statistical significant at $1 \%$ significant level and at $\mathrm{X}^{2}$ value $11.51^{* * *}$. This implies extension service positively and significantly determines household ingress decision on agricultural cooperative. 
Table 2. Descriptive statistics of household characteristics.

\begin{tabular}{|c|c|c|c|c|c|c|c|c|}
\hline \multirow{2}{*}{\multicolumn{2}{|c|}{ Explanatory variables }} & \multicolumn{2}{|c|}{$\begin{array}{l}\text { Participants } \\
(\mathrm{N}=110)\end{array}$} & \multicolumn{2}{|c|}{$\begin{array}{l}\text { Non- } \\
\text { participants } \\
(\mathrm{N}=110)\end{array}$} & \multicolumn{2}{|c|}{$\begin{array}{l}\text { Total } \\
(\mathrm{N}=220)\end{array}$} & \multirow[t]{2}{*}{$\mathbf{X}^{2}$} \\
\hline & & $\mathrm{N}$ & $\%$ & $\mathrm{~N}$ & $\%$ & $\mathrm{~N}$ & $\%$ & \\
\hline \multirow[t]{2}{*}{ Hhsex } & Male & 101 & 92 & 87 & 78.72 & 188 & 85.5 & $5.51 * *$ \\
\hline & Female & 9 & 8 & 23 & 21.28 & 32 & 14.5 & \\
\hline \multirow[t]{2}{*}{ Impseedus } & Used & 85 & 77.6 & 56 & 51 & 141 & 62.95 & $12.71 * * *$ \\
\hline & Not-used & 25 & 22.4 & 54 & 49 & 79 & 37.05 & \\
\hline \multirow[t]{2}{*}{ Othcredacc } & Haveacces & 17 & 15.79 & 31 & 35 & 48 & 25.2 & $6.57 * * *$ \\
\hline & No access & 93 & 84.21 & 79 & 67 & 172 & 74.8 & \\
\hline \multirow[t]{4}{*}{ Offfarm } & Have & 6 & 5.56 & 35 & 31.9 & 41 & 20.58 & $16.49 * * *$ \\
\hline & No & 104 & 93.44 & 75 & 68.1 & 179 & 79.41 & \\
\hline & Have & 93 & 84.2 & 50 & 45.7 & 143 & 62.9 & \\
\hline & awareness & 17 & 15.8 & 60 & 54.3 & 77 & 37.1 & $26.65 * * *$ \\
\hline \multirow[t]{3}{*}{ Khh } & No & & & & & & & \\
\hline & awareness & & 64.5 & 68 & 61.7 & 139 & 62.9 & \\
\hline & $\begin{array}{l}\text { Extension } \\
\text { access }\end{array}$ & 71 & 35.5 & 42 & 38.3 & 81 & 37.1 & \\
\hline Agrexte & No-access & 39 & & & & & & $11.51 * * *$ \\
\hline
\end{tabular}

Source: Own survey data, 2018 Note: $* * *<1 \%, * *<5 \%$ and $*<10 \%$ significance level of discrete variables.

3.1.2 Household characteristic for continuous variables

As shown below in table 3, there is significant different between agricultural cooperative members and nonmembers with respect to different household characteristics. With respect to household head educational level most of participants were literate, market distance high from their home further than non- members at $1 \%$ ( $t$-value 2.98 and 7.68 respectively) significance level. Also inferential result in table revealed that agricultural cooperative members household were use relatively more fertilizer than non-members and report that relatively produce high amount of wheat yearly which exhibit difference among both group statistically significant at $1 \%, 5 \%$ respectively. Generally, this implies that household head being literate, having high market distance, high fertilizer demand for agricultural activities and high producing potential positively and significantly affect household entrance decision on agricultural cooperatives.

Table 3. Descriptive statistic of households head characteristics.

\begin{tabular}{|c|c|c|c|c|c|}
\hline $\begin{array}{l}\text { Explanatory } \\
\text { variables }\end{array}$ & $\begin{array}{l}\text { Total } \\
(\mathrm{N}=220)\end{array}$ & $\begin{array}{l}\text { Participants } \\
(\mathrm{N}=110)\end{array}$ & $\begin{array}{l}\text { Non- } \\
\text { participants } \\
(\mathbf{N}=110)\end{array}$ & $\begin{array}{l}\text { Different in } \\
\text { Mean }\end{array}$ & t-Value \\
\hline & Mean(STD) & Mean(STD) & Mean(STD) & Mean & \\
\hline Hhsize & $4.5(0.72)$ & $5(0.74)$ & $4(0.71)$ & 1.00 & 1.16 \\
\hline Hhage & $43(0.98)$ & $42(0.97)$ & $44(1.001)$ & 2.00 & 0.27 \\
\hline Hhedu & $1.71(1.24)$ & $2.03(1.35)$ & $1.45(1.07)$ & 0.56 & $2.98 * * *$ \\
\hline Mktdist & $3.23(1.77)$ & $4.23(1.66)$ & $2.41(1.42)$ & 1.77 & $7.68 * * *$ \\
\hline Totafert & $160.2(102.4)$ & $186(134)$ & $138.6(59.04)$ & 48.23 & $3.13^{* * *}$ \\
\hline Landha & $1.06(0.705)$ & $1.15(0.77)$ & $0.98(0.64)$ & 0.16 & 1.5 \\
\hline WheatP & $1267(1064)$ & $1484(479)$ & $1091.5(1342)$ & 392.70 & $2.43 * *$ \\
\hline
\end{tabular}

Source: Own survey data, 2018 Note: $* * *<1 \%, * *<5 \%$ and $*<10 \%$ significance level of continues variables.

\subsection{Econometric Analysis}

As specified in the model specification part of study dependent variable is dummy variable indicating whether the household has been member of agricultural cooperative which takes a value of 1 and 0 , otherwise (not member). Before estimating the model, data were checked for occurrence of strong multicollinearity among explanatory variable by using appropriate diagnostic techniques. First, the presence of multicollinearity among continuous explanatory variable was tested using variance inflation factors (VIF). VIF to test association among the continuous independent variable and contingency coefficients for dummy independent variables. Therefore larger value of VIF show the having multicollinearity among explanatory variables and general rule indicate as have multicollinearty if the VIF of variable exceeds 10 (Gujarati, 1995). As revealed in appendix 2 the values of VIF for all continuous variables were found to be small that less than 10 which indicate data have no multicollinearty. Therefore, all continuous explanatory variables were included in logit model. In other way contingency coefficient were computed on data to check multicollinearty among discrete explanatory variables. The decision rule for contingency coefficient states that when its value approaches to $1(>0.75)$ there is a problem of multicollinearty among dummy variables. However, the data result of contingency coefficient value show less than or equal to 
0.389 this reveal absence of multicollinearty between dummy variable. This implies that no multicollinearty problem on both continuous and discrete explanatory variable.

\subsubsection{Marginal Effect for Logit Regression}

Logit model regression result was in essence explained by odd ratio for dummy variables and marginal effect for continuous variables. This part show how rural households' participation affected by hypothesised covariates negatively or positively also significantly. As shown below table 4, among that hypothesized covariates seven variables are significantly affect the participation of household's membership decision on agricultural cooperatives and remain are not significantly affect participation.

Table 4. Logit regression show factors that influence participation of households on cooperative

\begin{tabular}{|l|l|l|l|l|l|}
\hline Particp & Odds Ratio & Std. Err. & Z-value & $\mathrm{P}>|\mathrm{z}|$ & Marginal effect \\
\hline cons & .0007045 & .0013496 & -3.79 & $0.000^{* * *}$ & --------- \\
\hline Hhsex & 4.922179 & 3.546034 & 2.21 & $0.027^{* *}$ & 0.307721 \\
\hline Fmsize & .8211121 & .2862048 & -0.57 & 0.572 & -0.046939 \\
\hline Hhage & 1.063222 & .2756537 & 0.24 & 0.813 & 0.0145999 \\
\hline Hhedu & 1.389094 & .2477974 & 1.84 & $0.064^{*}$ & 0.0782702 \\
\hline Mktdist & 1.890728 & .2943352 & 4.09 & $0.000^{* * *}$ & 0.1516961 \\
\hline Offfarm & .4923579 & .3367076 & -1.04 & 0.300 & -0.158462 \\
\hline Totafert & 1.008992 & .0059997 & 1.51 & $0.032^{* *}$ & 0.002132 \\
\hline Land-ha & .7055217 & .3579858 & -0.69 & 0.492 & 0.083072 \\
\hline Othcredacc & .2126475 & .1253708 & -2.63 & $0.009^{* * *}$ & -0.319167 \\
\hline Agr-exte & 1.107991 & 0.214776 & 1.41 & $0.047^{* *}$ & 0.102382 \\
\hline Impseedus & 2.674317 & 1.406086 & 1.87 & $0.061^{*}$ & 0.223532 \\
\hline Wheatp & 1.000418 & .0001965 & 2.13 & $0.033^{* *}$ & 0.000099 \\
\hline Khh & 8.137809 & 4.452407 & 3.83 & $0.000^{* * *}$ & 0.436321 \\
\hline Number of obs. 220 & & Prob $>$ chi $^{2}-0.0000$ & \\
\hline LR chi ${ }^{2}(13)-106.48$ & \multicolumn{2}{l}{ Pseudo $\mathrm{R}^{2}-0.4555$} \\
\hline Source own
\end{tabular}

Source own survey result 2018, Note: $* * * \mathrm{p}<0.01, * * \mathrm{p}<0.05$ and $*<0.1$ significance level of explanatory variables.

\section{Factors that Significant affect household in agricultural cooperative from Model}

The logistic regression result shown in above table 4 , out of total thirteen hypothesized explanatory variables nine were found to influence household participation decision to inter in to agricultural cooperative at study area. These are household head sex (Hhsex), household head education level (Hhedu), market distance from their home (Mktdist), total fertilizer amount that household head used yearly (Totafert), have other credit access for households (Othcredacc), agricultural extension service (Agr-exte), households using improved seed (Impseedus), house hold head wheat producing capacity (Wheatp) and household head knowledge about agricultural cooperative (Khh). These significantly influencing variables are discussed in detail as following section.

\section{Household head sex and participation on cooperative}

Sex of household head was positively related and the coefficient is different from zero at 5\% significance level. Holding all other variable in model constant as a discrete change in household head from female to male probability of household to participate in agricultural cooperative increase at about 0.308 or 30.8 percent. This implies household head with male have more significant probability to participate and join in agricultural cooperative. Conceivable reason is cultural female were not participate at any kind of meeting and on community work this may ease their participation on agricultural cooperative. The result have consistence former study with Fanaye and Thomas (2012) their finding show that participation of male headed household is $76 \%$ and female headed household have only 24\% also NKurunziz and Ngabitsinza (2015) in Keny show that female headed house have negative and significantly affect household participation on agricultural cooperatives .

\section{Household head education and participation on cooperative}

Education of household head is positively correlated with household participation on agricultural cooperative and the coefficient is significantly different from zero at $10 \%$ significance level. As education level of household head increase by one year schooling probability of household to participate in agricultural cooperative (being member) increase by 0.078 or 7.8 percent. The possible reason household with high educate level understand, accept new thing and accordingly they can realize their benefit from agriculture cooperative. In short it implies high education level of education enhance with knowledge and skill, hence those facilitate awareness on importance membership on agricultural cooperatives. This result is more consistent with other previous study finding like Eshetu and Assefa (2015) also Dejene and Matthews (2016), that their result show education has positive and significant influence on household participation. But it is inconsistence with finding of NKurunziz, I (2012) revealed that household education influence negative decision to participate in cooperatives.

Market distance and amount of fertilizer that household used

Market distance and probability of household that participates on agricultural cooperative correlate positively and 
coefficient is also different from zero at $1 \%$ significance level. Holding constant other determinants that hypothesized in model market distance increase by one unit (1 kilo metre) from their home participation of household increase by 0.156 or 15.17 percent. Agricultural cooperative provide marketing service spatially for who farmers that produce cereal product therefore household that have no market access near, they participate on agricultural cooperative in order to get market for their agricultural product.

Also as show in above table, fertilizer amount that household used for agricultural production is positively associated with household participation on agricultural cooperatives and coefficient is different from zero at 5\% significance level. Holding all other variables that included in a model constant a fertilizer amount that household use increase by 1 kilo gram household participation increase by 0.2 percent.

\section{Household with other credit access}

Other credit access was negatively correlated with household participation on agricultural cooperative (membership) and coefficient is different from zero at $1 \%$ significance level. This show having high negative statistically significant correlation between household decisions to participate on agricultural cooperatives. Holding all other variables in the model constant at their mean values, a discrete change in other credit access from zero to one, probability of household decision to be a member (participate) on agricultural cooperative decrease at about 0.319 or by 31.9 percent. Possible reason is if household might have access of credit specially for agricultural input purchasing may have low interest to participate in agricultural cooperative. This result convince NKurunziza, I and Ngabitsinza (2015) findings show that farmers who have no access to credit more participate on cooperative that show positive and significant influence. However inconsistence with finding of Muthyalu (2013) that reveal that being membership on other cooperative influence household participation on agricultural cooperative positively and significantly.

\section{Proper agricultural extension service}

Agricultural extension defined as types of service that agricultural office and marketing and cooperative sector engage in order to satisfy the need of members as well as non-members. Agricultural extension service was positively correlated with household participation (membership) on cooperatives and coefficient is also different from zero at 5\% significance level. Holding all other variable that hypothesized in a model on their mean value, a discrete change on agricultural extension service from zero to one, probability of household decision to be a member (participate) on agricultural cooperative increase at about 0.1024 or by 10.24 percent. This might be because when household get regular extension service from agriculture DAs, cooperative, and from other stakeholders, farmers more aware about cooperative and become likely to participate on agricultural cooperatives. This result is consistent with finding of Eshetu and Assefa (2015) and with finding of Dejene and Matthews (2016). Improved seed practice and wheat production capacity of household

Analysis result in above table reveal that household those have more practice in using improved seed have high probability to participate on agricultural cooperatives. This implies that a positive correlation between household improved seed using practice and on their participation at agricultural cooperatives also the coefficient show as different from zero at $10 \%$ significance level. Holding all other variables that included in model on their mean value (constant), a discrete change on household practice to use improved agricultural seed from zero to one, the probability of households' decision to participate on agricultural cooperative increase at about 0.2235 or by 22.35 percent.

Findings also revealed that household wheat production capacity influence the participation of households in agricultural cooperative positively and the coefficient is different from zero at 5\% significance level. Result show in table above holding all other variables of the model that hypothesized in constant a wheat producing amount of household increase by a unit (kilo gram) household participation decision of household increase by 0.009 percent. Agricultural cooperatives warmly buy farmers cereal product at current price and sell it when price increase at the end of year share dividend. This might be the reason for households who have high wheat producing capacity more probably participate on agricultural cooperative in order to get dividend.

\section{Household awareness about agricultural cooperative service}

The last result in above table show that household's knowledge about agricultural cooperatives service with household participation decision on agricultural cooperative positively and coefficient is different from zero at $1 \%$ significance level. Holding other variable constant (at their mean value), a discrete change on household to have knowledge about agricultural cooperative from zero to one probability of household decision to be a member of cooperative increase by 0.436 or 43.6 percent.

\subsection{Conclusion and Recommendation}

The study was conducted in Hadiya zone in case of Ana Lemo district agricultural cooperatives, to analysis factors that determine a farmer's membership increment on agricultural cooperative. For analysis of factors that affecting farmers' membership on agricultural cooperatives was analysed by using both descriptive statistic (t-test continuous and Chi-square for discrete variables) and econometric binary logistic model. Descriptive statistic result revealed most of variables determine households participation on agricultural cooperative that household 
curiosity in using improved agricultural input, having adequate agricultural extension service, household education level, yearly fertilizer amount that households used, wheat production capacity rather than other cereal production and household acquaintance about cooperatives provision have positive and significantly determine household participation on agricultural cooperative. In supplementary having credit access from other institution, off-farm income and market distance from their home negatively associated and significantly affect household's participation on cooperative membership. Within similar variables logit regression result revealed that some factors determine participation of households on membership in agricultural cooperatives at $1 \%$ significance level like market distance from their house, access of credit via other institution and devour of awareness on services of cooperatives. In other side some at 5\% significance level those fertilizer amount households that used, household head being male, agricultural extension that provided for households and appearances of households in wheat production rather than other cereal. Lastly, household head education level and household demand of improved seed determine participation of rural household's membership on agricultural cooperatives at $10 \%$ significance level in Ana Lemo district

The study shows that agricultural extension service and awareness about agricultural cooperatives benefit, ideology and nature have significant and positive relation with household membership decision. Based on this reality, government, cooperative institution and other stakeholder should exert effort in extension service and awareness creation surrounding benefit, nature and ideology of agricultural cooperative. In other side households both member and non-member of agricultural cooperatives that use improved agricultural seed and fertilizer affect household participation and correlate hence government and cooperatives should support household in order to increase their usage of those agriculture input to increase membership. Similarly governments should include on its policy and give more reflexion on awareness creation on practise of agricultural improved seed and fertilizer. In case of market distance from their house and access of credit from other financial institution both significantly affect their participation and have negative association and so government, agricultural cooperatives and other financial institution should give recognition.

\section{Reference}

Abate G. T., Francesconi G. N. and Getnet K. 2013, “Impact of agricultural cooperatives on smallholders' technical efficiency: evidence from Ethiopia".

Abel, W. 2017. Impact of Cooperatives on Poverty Reduction: The Case of Licha Hadiya Farmers' Cooperative Union in Lemo Woreda; Hadiya Zone, SNNPR, Ethiopia, Vol 35.

ALWFEDO, 2018. Ana Lemo Woreda Finance and Economic Development office yearly report.

Birchall, J. (2003). Rediscovering the Co-operative Advantage: Poverty Reduction through Self-help, Geneva: ILO.

Burgess, R, and Pande, R. 2003. Do Rural Banks Matter?; Evidence from the Indian social banking experiment research paper.

Dejen, D and Matthews, H. 2016. Factors Affecting Farmers' Cooperative Membership Increment; in Bench Maji Zone, Southwestern Ethiopia, Vol.6, No.2.

Eshetu, T and Assefa G/H/W, 2015. Performance and Determinants of Household's Participation in Dairy Marketing Cooperatives: The Case of Lemu-Arya and Bekoji Dairy Marketing Cooperatives, Arsi Zone, Oromia Region, Ethiopia

International Fund for Agricultural Development, 2013. Independent office evaluation learning for better rural livelihoods; Report in united nation international year of cooperative, report No.2780

Kimberly, A. Zeuli and Robert, C. 2004. Cooperatives: Principles and Practices in the 21st Century. Cooperative Extension Publishing, University of Wisconsin, Medison, USA.

International Co-operative Alliance (ICA), 1995. Statement on the Co-operative identity, in review of international cooperation, Vol.88,No.30.

ILO and ACA, 2012. Cooperative and sustainable development goals; contribution to the post-2015 development debate report.

Jakob B. Madsen, 1998. "Book review: Basic Econometrics, Damodar N. Gujarati, McGraw-Hill, New York, 1995," Journal of Applied Econometrics, John Wiley \& Sons, Ltd., vol. 13(2).

MOFED (Ministry of Finance and Economic Development), 2006. Ethiopia: Building on Progress-A Plan for Accelerated and Sustained Development to End Poverty (PASDEP) (2005/06- 2009/10) Volume I

Shiferaw, B. 2012. Agricultural cooperative key for food security, MoA. Available at: http://allafrica.com/stories/201210190202.html [27 Sep. 2013].

Smith, S. \& Ross, C. 2006. How the SYNDICOOP approach has worked in East Africa. (Geneva, ILO, ICA and ICFTU).

ZerihunAlemayehu, (1998). Cooperatives Movement in Ethiopia, Unpublished paper presented in the National Workshop in Addis Ababa, Ethiopia 